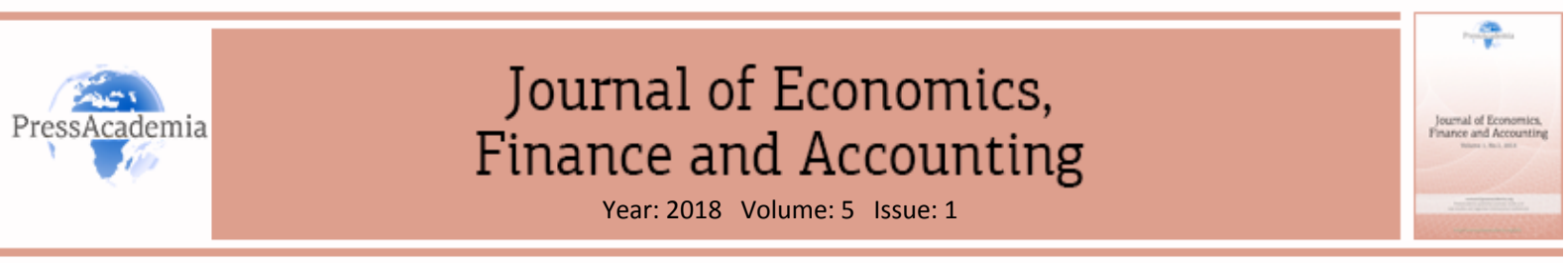

\title{
EVALUATION OF THE PERFORMANCE OF TURKISH EQUITY UMBRELLA FUNDS USING THE MORNINGSTAR RATING SYSTEM
}

\author{
DOI: 10.17261/Pressacademia.2018.789 \\ JEFA- V.5-ISS.1-2018(11)-p.127-136 \\ Yavuz $\mathrm{Gul}^{1}$, Serpil Altinirmak ${ }^{2}$ \\ ${ }^{1}$ Anadolu University, Department of Finance, Eskisehir, Turkey. \\ yavuz.gul@outlook.com, https://orcid.org/0000-0002-0208-6798 \\ ${ }^{2}$ Anadolu University, Deparment of Finance, Eskisehir, Turkey. \\ saltinirmak@anadolu.edu.tr, https://orcid.org/0000-0003-2879-9902
}

\section{To cite this document}

.. Gul, Y. Altinirmak, S. (2018). Evaluation of the performance of Turkish equity umbrella funds using the Morningstar rating system. Journal of Economics, Finance and Accounting (JEFA), V.5(1) p.127-136

Permemant link to this document: http://doi.org/10.17261/Pressacademia.2018.789

Copyright: Published by PressAcademia and limited licenced re-use rights only.

\begin{abstract}
Purpose - Different types of funds exist depending on the assets the portfolio is composed of. The main types of funds include; bond umbrella funds, equity umbrella funds, precious metal umbrella fund, fund basket umbrella funds, money market umbrella funds, participation umbrella fund, balanced umbrella funds, free umbrella funds, guaranteed umbrella fund, umbrella fund for protection purposes.The subject of our study is equity umbrella funds. These kinds of funds receive at least $80 \%$ of the share of investment by domestic and/foreign issuers. Purpose of this study is evaluating the performance of 57 Turkish equity umbrella funds which operate continuously between January 2012-December 2016 by using Morningstar rating system.

Methodology - The Morningstar (star) rating system, which has proven to be an effective system for ranking mutual funds, has become the focus of both academic work and applications. This system, developed by Morningstar, ranks the performance results of mutual funds by assigning them 1 to 5 stars according to their adjusted risks.

Findings - The results of the study reveal a lack of effective management of the equity umbrella funds, and that they perform below Treasury bond yields. The mutual funds, consequently, showed overall negative Morningstar performance results. It was determined that while foreign equity weighted mutual funds are more successful, mutual funds that invest in equity in the index are not quite successful. Conclusion- The study used the Morningstar rating system to evaluate 57 equity umbrella funds operating in Turkey between the periods of January 2012 and December 2016. The results obtained in the study regarding performance rankings and performance are not meant as a prediction of the future performance of the concerned funds, they are only intended to assess the value of the equity umbrella funds at a specific period in the past using an internationally accepted rating system. The data obtained indicated that the equity umbrella funds have an overall negative Morningstar performance.

The equity umbrella funds are considered to be underperforming since they performed poorly compared to the Treasury bills used in the study. Under the assumption that past performance results will continue in the future, it is thought that the results are meaningful and should be followed.
\end{abstract}

Keywords: Equity umbrella funds, performance, morningstar rating, risk, fund management JEL Codes: G11, G23,G24

\section{INTRODUCTION}

Collective investment institutions are known as investment trusts when they are established as separate and independent legal entity according to the legal structures, and as mutual funds when they are established within the scope of a contract by another legal entity. Mutual funds collect money from the public in exchange of partnership shares, and, on their behalf, manage portfolios made of securities such as equity and bonds, and precious metals. By owning a share that represents part of the portfolio owned by the mutual fund each investor becomes a partner to the fund's portfolio. Thus, when investors sell their shares, they receive their share of the increase/decrease in the portfolio of the mutual fund up to the time (www.spk.gov.tr/Sayfa/AltSayfa/253). 
Just as one can become a partner to a company by owning its equity, so can they become a partner to a mutual fund portfolio with share certificate. When an investor invests in an investment fund, a new share is added to the fund leading to an increase in the size and number of shares in the fund. The money of the new investor is combined with the money of the other investors. Portfolio managers then invest (including the new shares) in various investment instruments.

Small investors, with small savings, get to enjoy the advantage of professionally managed and diversified portfolios of different securities by the mutual fund. This situation also reduces the risk. In addition, investors can convert their investments and the realized earning into cash whenever they feel the need.

The biggest mistake people commit when deciding on which investment fund to invest in is trying to compare apples and oranges. The asset class making the investment fund is of great importance. Let's say we have invested in a gold fund, if the fund earns $25 \%$ when gold increases by $30 \%$ then it is clear we are dealing with a non-successful fund. Or, if an equity fund loses only $25 \%$ when the BIST 100 index falls by $30 \%$, then we say it is an effectively managed fund. For this reason, the success of a fund is only measured by the performance of the asset class it invests in compared to the benchmark.

When choosing a fund as an investor, it is necessary to consider one's risk and return preferences. Mutual funds take different names depending on the assets they invest in. In this study, equity weighted funds are considered.

The most basic way to measure the success of an investment fund is by comparison with the result of the benchmark that the identified by fund. However, this comparison alone may not be enough due to the complex structure of the industry. For this reason, there is a continuous academic effort in this area of work.

It is possible, though, to say that the following three sector ratios are used to a considerable extent for actively managed funds.

Sharpe Ratio: The return on any portfolio corresponds to the risk that the investor is exposed to. The risk here is standard deviation. The Sharpe ratio is based on the comparison between the residual return and the risk involved in achieving this return (Sharpe, 1966:119). The Sharpe index indicates the total risk of the portfolio vis a vis the additional return demanded by the investor at the risk-free interest rate (Civan, 2010:339). The Sharpe index calculated for any portfolio is not significant by itself. This index needs to be compared with other portfolios or with the market portfolio. The ranking of the performance is then done from the highest to the lowest value. If the value obtained for this portfolio is as high as the others, then the portfolio can be said to a high performer (Sharpe, 1966:120).

Treynor Ratio: the ratio takes into account the sensitivity (beta) of the portfolio index. Like in Sharpe ratio, Treynor ratio considers the systematic risk that reflects the market risk as opposed to the total risk the portfolio is faced with (Treynor, $1965 ; 64)$. According to Treynor, in order to obtain a satisfactory measure of performance, the first requirement is to establish a relationship between the expected return of the portfolio and an appropriate market return rate. Treynor states that besides the risk arising from fluctuations in the market, a portfolio that is well diversified faces the risks arising from fluctuations in the value of each of the securities making up the portfolio. He asserts that trying to assess the performance of a portfolio at a given time period by looking at the average return of that portfolio may be deceptive (Treynor, 1965).

Jensen Performance Index: The performance of a portfolio is measured using a single value. This value is the alpha, which is the coefficient of the constant term of the regression equation formed between the returns of the fund and the market returns (Ayaydın, 2013:67). When calculating the Jensen's measure, the alpha coefficient is calculated by subtracting the return obtained according to the capital asset pricing model (CAPM). The performance is determined by whether the alpha coefficient is positive or negative. A positive alpha indicates that the portfolio manager is successful while negative alpha shows that the manager has failed (Aksoy and Tanrı̈ven, 2007:661).

In this study, we use Morningstar rating system to obtain and evaluate performances of Turkish equity umbrella funds during the period January 2012-December 2016

\section{LITERATURE REVIEW}

Loviscek and Jordan (2000) used the Morningstar method in selecting the best portfolios to be chosen by mutual funds. They didn't find results that could be applicable to individual investors. However, when Guercio and Tkac (2002) investigated the Morningstar effect by estimating the star's value in terms of the asset flow generated for a typical fund, they found the Morningstar rating to be a unique strength in influencing asset flow. Morey and Vinod (2001) tried to find out the risk of estimating the performance by the system. In his study, Morey (2002) revealed the age bias of the Morningstar system. He found that older funds received higher star ratings than younger funds. In 2004, however, Adkisson and Fraser (2003) investigated the sources of age bias. They have found evidence that the age bias persisted even if the market conditions shifted from bullish to bearish market conditions.

Morey (2003) found that funds that received 5 stars changed their portfolio at the end of the first year. For this reason, Morey cautioned investors against using a 5 -star rating as a performance signal for the 3 years following the rating. 
Morey and Gottesman (2006) conducted a review of how a new Morningstar rating system predicts future fund performance. They observed and concluded that a new Morningstar performance system, created from 3 different methodologies based on 4 different performance metrics, provided a great support in forecasting future performance in the first 3 years. They pointed out that high-rated funds, especially, perform significantly better than low-rated funds. These results contrast the results of Morey (2002) and Blake and Morey (2000) which show that the old Morningstar rating system does not predict future performance well.

Gerrans (2006) noted that the Morningstar rating system as used in Australia is a useful source of information for investors, and that in time, the system will come to command a similar position in North America. However, he also noted that Morningstar is not a force that can be predicted.

Knuutila, Puttonen and Smythe (2007) concluded that in Finland, funds that had 5-star Morningstar ratings, but which were not managed by banks registered good performance in terms of high cash flows, which was not the case for funds managed by banks. Antypas et al. (2009) conducted a different research in which they concluded that the Morningstar rating system is more effective in selecting the worst performing funds as opposed to the best performers. However, Kaur and Liu (2010) found conflicting results in their study of Canadian equity mutual funds. The study performed dummy variable regression analysis using three performance measures (Sharpe ratio, Jensen's alpha and two-index alpha). They found that higherrated funds showed significantly better performance than the lower-rated funds.

Barron and Ni (2013) studied the effects of Morningstar ratings on mutual fund replacement. They found that Morningstar ratings by themselves did not affect the probability of a fund managers being changed even though they had better predictive performance on manager change than other alternatives that measured fund performance.

Chotivetthamrong (2015) proved that in Thailand, upon receiving high ratings like 5 stars, fund performances in terms of size fell heavily. Bolster et al. (2016) evaluated the performance of portfolios created using the Morningstar system. The results provide evidence that the Morningstar equity rating system helps investors in the formulation of portfolios that give long-term, high-risk adjusted returns. It was concluded that the system could be used to distinguish between long-term undervalued and overvalued equity.

\section{DATA AND METHODOLOGY}

The "Morningstar Star Rating System", used by the Morningstar company in rating investment funds, is one of the most widely used performance measurement systems in the US since the 1980s (Sindell, 2005: 30).

In the Morningstar star rating, just like it is done for hotels, movies and restaurants, investment funds are assigns stars from 1 to 5 where 5 stars represents the best performing investment fund, and 1 star represents the worst performing investment fund (Morey, 2002; 56). In this respect, the Morningstar rating system helps in making better investment decisions, at least theoretically, by determining the quality of the funds when investors are faced with the challenge of choosing from thousands of funds (Apak and Taşçıan, 2009:82).

It is assumed that a fund crowned as 5-Star by the Morningstar star rating system will be preferred more and more by the public just like other high performing products. Examples of this have been observed in America where, for instance, it was recorded that of the investments made in the period of January - August of $199590 \%$ went to investment funds assigned 4 and 5 stars while funds with 3 stars or less experienced mostly negative cash flows. Similarly, a research conducted by the Financial Research Corporation of Boston in 1999 found that while the 4 and 5-star funds received a cash inflow of 223.6 million dollars in the year, funds with 3 stars or less had a negative cash flow to the tune of 132 million dollars (Apak and Taşcıyan, 2009:82).

\subsection{The Application Steps of Morningstar Star Rating System}

Step One: First, the Morningstar return is calculated for periods for 3,5 and 10 years. To do this, first of all, the "adjusted return" is calculated by deducting all commission and management expenses from the return of the investment fund. Then the adjusted return in excess of the 90-day interest rate is found. Finally, the Morningstar return ratio is obtained by dividing the resulting figure by the greater of the two variables given: The difference between the average return of the category and the 90-day average Treasury bill, or the 90-day average Treasury bill.

Morningstar Return $=\frac{\text { Adjsuted Return on the Fund-Treasury Bill }}{(\text { Average Category Return -Treasury Bill) } \text { or Treasury Bill }}$

According to the formula above, the result of the equation actually can be called 'load-adjusted relative return'. Morningstar divides one of these two variables in order to avoid distortion which might occur because of the low or negative average excess returns in the denominator of equation. If the adjusted return obtained by deducting management expenses and the return on the commission is equal to the average category return, then the Morningstar return will be 
equal to 1 . However, if the return on the fund is less than the average category return, Morningstar return will be less than 1 and vice versa.

Step Two: The second step of the star rating process is the calculation of the Morningstar risk. Here, the maximum risk is taken as the measure of risk. The risk of the fund is compared to the maximum risk calculated for the category. The Morningstar risk for the relevant period is obtained by dividing the maximum risk calculated for the fund by the maximum risk of the relevant category.

Step Three: the raw score is obtained by deducting the Morningstar risk from the Morningstar return calculated for 3, 5 and 10 -year periods.

Step Four: The raw score for each period is weighted depending on the age of the fund.

- $\quad$ For funds with less than 5 years but more than 3 years of return data (young funds) Morningstar weights the 3year star rating by 100 percent.

- $\quad$ For funds with less than 10 years but more than 5 years of return data (middle-aged funds) Morningstar weights the 3-year star rating by 60 percent and the 5 -year star rating by $40 \%$.

- $\quad$ For funds with more than 10 years of return data (seasoned funds) Morningstar weights the 3-year star rating by 20 percent, the 5 -year star rating by $30 \%$ and the 10 -year star rating by $50 \%$.

Fifth Step: The final star rating is done according to the weights calculated for each of the funds. The funds score that reach the top $10 \%$ in the category receive a time-specific rating of 5 stars; funds in the next $22.5 \%$ receive a time-specific star rating of 4 stars; funds in the middle $35 \%$ receive a time-specific rating of 3 stars; those in the next $22.5 \%$ receive a timespecific rating of 2 stars, and those in the bottom $10 \%$ receive a time-specific rating of 1 star.

The Morningstar star rating system has been the subject of several academic studies. In his (1998) study, Blume made reference to a rating system by the Chicago based Morningstar company that rates the investment performance of mutual funds by assigning the 1 to 5 stars. Blake and Morey (2000) used the Morningstar rating system as a forecasting system for the performance of local capital funds. As a result, they found that the Morningstar system performs slightly better than other alternatives in estimating future performance of funds.

\subsection{Calculation of Returns}

The first step in the Morningstar fund rating system is to calculate the returns to be used to measure fund performance. In the study, the 60-month return (\%) data for 57 equity umbrella funds covering the period between January 2012 and December 2016 were used. This data is obtained from the CMB (Capital Markets Board) website. Month end unit prices were used to make calculations. The returns of the equity intensive mutual funds were calculated using the following formula.

$$
r_{p}=\frac{V_{t}-V_{t-1}}{V_{t-1}}
$$

$r_{p}=$ Monthly return of the mutual fund

$V_{t}=$ Month end unit price for the mutual fund

$\mathrm{V}_{\mathrm{t}-1}=$ Previous month end unit price for pension mutual fund

In the next stage, the excess return on the funds' risk-free interest rate (Treasury bills) is calculated. Morningstar return is calculated by dividing the difference between the adjusted average return of a fund from the average return of the treasury bill by either (whichever is larger) the excess return on the average of the category fund or the average treasury bill return. The study used the monthly returns of 91-day Treasury bills to represent risk-free returns.

\subsection{Calculating Risk}

The Morningstar star rating system considers the maximum risk as the measure of risk. The Morningstar risk is obtained by dividing the maximum risk calculated for the fund by the maximum risk of the relevant category. In the calculation of risk, there are months in which the fund's returns in excess of the risk-free interest rate were negative. The negative returns are summed, and the resulting figure divided by the number of months in the calculation period.

\section{FINDINGS AND DISCUSSIONS}

Fund data which we used to obtain Morningstar results was provided from the website of Capital Markets Board of Turkey. The results of 57 equity umbrella funds according to the Morningstar risk rating system are shown in Table 1. According to 
the results, there are 6 equity umbrella funds with 5-star rating, 13 equity umbrella funds with 4-star rating, 19 equity umbrella funds with 3-star rating, 13 equity umbrella funds with 2-star rating and 61 -star rated equity umbrella funds.

Table 1: Morningstar Ratings of Funds

\begin{tabular}{|c|c|c|c|c|c|c|c|}
\hline RANK & FUNDS & $\begin{array}{l}3 \text { YEAR RAW } \\
\text { YIELD *0,4 }\end{array}$ & $\begin{array}{c}3 \text { YEAR } \\
\text { STAR }\end{array}$ & $\begin{array}{l}5 \text { YEAR RAW } \\
\text { YiELD *0,6 }\end{array}$ & $\begin{array}{l}5 \text { YEAR } \\
\text { STAR }\end{array}$ & $\begin{array}{l}\text { MORNINGSTAR } \\
\text { SCORE }\end{array}$ & $\begin{array}{c}\text { MORNINGSTAR } \\
\text { RATINGS }\end{array}$ \\
\hline 1 & $\begin{array}{l}\text { Ak Asset } \\
\text { Management } \\
\text { America Foreign } \\
\text { Equity Fund }\end{array}$ & 0,758 & $* * * * *$ & 0,690 & $* * * * *$ & 0,717 & $* * * * *$ \\
\hline 2 & $\begin{array}{l}\text { Ak Asset } \\
\text { Management } \\
\text { European Foreign } \\
\text { Equity Fund }\end{array}$ & 0,365 & $* * * * *$ & 0,078 & $* * * * *$ & 0,193 & $* * * * *$ \\
\hline 3 & $\begin{array}{l}\text { Yapı Kredi Asset } \\
\text { Management } \\
\text { Foreign } \\
\text { Technnology } \\
\text { Sector Equity } \\
\text { Fund }\end{array}$ & 0,091 & $* * * * *$ & 0,050 & $* * * * *$ & 0,067 & $* * * * *$ \\
\hline 4 & $\begin{array}{l}\text { Ak Asset } \\
\text { Management } \\
\text { Foreign Securities } \\
\text { Fund }\end{array}$ & $-0,113$ & $* * * * *$ & $-0,027$ & $* * * * *$ & $-0,062$ & $* * * * *$ \\
\hline 5 & $\begin{array}{l}\text { Gedik Asset } \\
\text { Management G- } \\
20 \text { Countries } \\
\text { Foreign Securities } \\
\text { Fund }\end{array}$ & $-0,622$ & $* * * * *$ & $-0,564$ & $* * * * *$ & $-0,587$ & $* * * * *$ \\
\hline 6 & $\begin{array}{l}\text { Strateji Asset } \\
\text { Management } \\
\text { Second Equity } \\
\text { Fund }\end{array}$ & $-0,770$ & $* * * *$ & $-1,003$ & $* * * * *$ & $-0,910$ & $* * * * *$ \\
\hline 7 & $\begin{array}{l}\text { İş Asset } \\
\text { Management } \\
\text { Participation } \\
\text { Equity Fund }\end{array}$ & $-0,595$ & $* * * * *$ & $-1,163$ & $* * * *$ & $-0,936$ & $* * * *$ \\
\hline 8 & $\begin{array}{l}\text { Ak Asset } \\
\text { Management Asia } \\
\text { Foreign Equity } \\
\text { Fund }\end{array}$ & $-1,082$ & $* * * *$ & $-1,485$ & $* * * *$ & $-1,324$ & $* * * *$ \\
\hline 9 & $\begin{array}{l}\text { İstanbul Asset } \\
\text { Management } \\
\text { Equity Fund }\end{array}$ & $-0,943$ & $* * * *$ & $-1,642$ & $* * * *$ & $-1,362$ & $* * * *$ \\
\hline 10 & $\begin{array}{l}\text { İş Asset } \\
\text { Management } \\
\text { BIST Technology } \\
\text { Index Equity Fund }\end{array}$ & $-2,052$ & $* * * *$ & $-1,348$ & $* * * *$ & $-1,630$ & $* * * *$ \\
\hline 11 & $\begin{array}{l}\text { Ziraat Asset } \\
\text { Management } \\
\text { Dividend Paying } \\
\text { Corporations } \\
\text { Equity Fund } \\
\end{array}$ & $-1,793$ & $* * * *$ & $-2,060$ & $* * * *$ & $-1,953$ & $* * * *$ \\
\hline 12 & $\begin{array}{l}\text { Gedik Asset } \\
\text { Management } \\
\text { Second Equity } \\
\text { Fund }\end{array}$ & $-1,834$ & $* * * *$ & $-2,037$ & $* * * *$ & $-1,956$ & $* * * *$ \\
\hline
\end{tabular}




\begin{tabular}{|c|c|c|c|c|c|c|c|}
\hline 13 & $\begin{array}{l}\text { Tacirler Asset } \\
\text { Management } \\
\text { Equity Fund }\end{array}$ & $-2,387$ & $* * * *$ & $-1,798$ & $* * * *$ & $-2,033$ & $* * * *$ \\
\hline 14 & $\begin{array}{l}\text { Ak Asset } \\
\text { Management BRIC } \\
\text { Countries Foreign } \\
\text { Equity Fund }\end{array}$ & $-2,362$ & $* * * *$ & $-1,861$ & $* * * *$ & $-2,061$ & $* * * *$ \\
\hline 15 & $\begin{array}{l}\text { Yapı Kredi Asset } \\
\text { Management Koc } \\
\text { Holding Affiliate } \\
\text { and Equity Fund }\end{array}$ & $-2,421$ & $* * * *$ & $-2,306$ & $* * * *$ & $-2,352$ & $* * * *$ \\
\hline 16 & $\begin{array}{l}\text { Azimut PYŞ First } \\
\text { Equity Fund }\end{array}$ & $-2,300$ & $* * * *$ & $-2,441$ & $* * * *$ & $-2,385$ & $* * * *$ \\
\hline 17 & $\begin{array}{l}\text { Fokus Asset } \\
\text { Management } \\
\text { Equity Fund }\end{array}$ & $-2,196$ & $* * * *$ & $-2,588$ & $* * * *$ & $-2,431$ & $* * * *$ \\
\hline 18 & $\begin{array}{l}\text { Qinvest Asset } \\
\text { Management } \\
\text { Equity Fund }\end{array}$ & $-2,445$ & $* * * *$ & $-2,548$ & $* * * *$ & $-2,507$ & $* * * *$ \\
\hline 19 & $\begin{array}{l}\text { Bizim Asset } \\
\text { Management } \\
\text { Energy Sector } \\
\text { Equity Fund }\end{array}$ & $-2,708$ & $* * *$ & $-2,666$ & $* * * *$ & $-2,683$ & $* * * *$ \\
\hline 20 & $\begin{array}{l}\text { İş Asset } \\
\text { Management } \\
\text { İsbank } \\
\text { Subsidiaries Fund }\end{array}$ & $-2,781$ & $* * *$ & $-2,705$ & $* * *$ & $-2,736$ & $* * *$ \\
\hline 21 & $\begin{array}{l}\text { Ziraat Asset } \\
\text { Management } \\
\text { Equity Fund }\end{array}$ & $-2,593$ & $* * *$ & $-2,927$ & $* * *$ & $-2,794$ & $* * *$ \\
\hline 22 & $\begin{array}{l}\text { Gedik Asset } \\
\text { Management First } \\
\text { Equity Fund }\end{array}$ & $-2,471$ & $* * * *$ & $-3,037$ & $* * *$ & $-2,810$ & $* * *$ \\
\hline 23 & $\begin{array}{l}\text { Şeker Asset } \\
\text { Management } \\
\text { Equity Fund }\end{array}$ & $-2,865$ & $* * *$ & $-2,983$ & $* * *$ & $-2,936$ & $* * *$ \\
\hline 24 & $\begin{array}{l}\text { Kare Asset } \\
\text { Management } \\
\text { Equity Fund }\end{array}$ & $-2,933$ & $* * *$ & $-2,972$ & $* * *$ & $-2,956$ & $* * *$ \\
\hline 25 & $\begin{array}{l}\text { Ata Asset } \\
\text { Management First } \\
\text { Equity Fund }\end{array}$ & $-2,864$ & $* * *$ & $-3,122$ & $* * *$ & $-3,019$ & $* * *$ \\
\hline 26 & $\begin{array}{l}\text { Strateji Asset } \\
\text { Management First } \\
\text { Equity Fund }\end{array}$ & $-3,367$ & $* * *$ & $-2,907$ & $* * *$ & $-3,091$ & $* * *$ \\
\hline 27 & $\begin{array}{l}\text { Finans Asset } \\
\text { Management First } \\
\text { Equity Fund }\end{array}$ & $-2,877$ & $* * *$ & $-3,364$ & $* * *$ & $-3,169$ & $* * *$ \\
\hline 28 & $\begin{array}{l}\text { Global MD Asset } \\
\text { Management First } \\
\text { Equity Fund }\end{array}$ & $-3,188$ & $* * *$ & $-3,378$ & $* * *$ & $-3,302$ & $* * *$ \\
\hline 29 & $\begin{array}{l}\text { Global MD Asset } \\
\text { Management } \\
\text { Second Equity } \\
\text { Fund }\end{array}$ & $-3,356$ & $* * *$ & $-3,290$ & $* * *$ & $-3,317$ & $* * *$ \\
\hline 30 & $\begin{array}{l}\text { Iş Asset } \\
\text { Management }\end{array}$ & $-3,305$ & $* * *$ & $-3,343$ & $* * *$ & $-3,328$ & $* * *$ \\
\hline
\end{tabular}




\begin{tabular}{|c|c|c|c|c|c|c|c|}
\hline & $\begin{array}{l}\text { Privia Private } \\
\text { Equity Fund }\end{array}$ & & & & & & \\
\hline 31 & $\begin{array}{l}\text { İş Asset } \\
\text { Management } \\
\text { Dividend Paying } \\
\text { Corporations } \\
\text { Equity Fund }\end{array}$ & $-3,363$ & $* * *$ & $-3,387$ & $* * *$ & $-3,377$ & $* * *$ \\
\hline 32 & $\begin{array}{l}\text { İş Asset } \\
\text { Management } \\
\text { Equity Fund }\end{array}$ & $-3,404$ & $* * *$ & $-3,407$ & $* * *$ & $-3,405$ & $* * *$ \\
\hline 33 & $\begin{array}{l}\text { Bizim Asset } \\
\text { Management } \\
\text { Construction } \\
\text { Sector } \\
\text { Equity Fund }\end{array}$ & $-3,440$ & $* *$ & $-3,407$ & $* * *$ & $-3,420$ & $* * *$ \\
\hline 34 & $\begin{array}{l}\text { Ak Asset } \\
\text { Management } \\
\text { Equity Fund }\end{array}$ & $-3,334$ & $* * *$ & $-3,481$ & $* * *$ & $-3,422$ & $* * *$ \\
\hline 35 & $\begin{array}{l}\text { Yapı Kredi Asset } \\
\text { Management First } \\
\text { Equity Fund }\end{array}$ & $-3,414$ & $* * *$ & $-3,478$ & $* * *$ & $-3,452$ & $* * *$ \\
\hline 36 & $\begin{array}{l}\text { ING Asset } \\
\text { Management First } \\
\text { Equity Fund }\end{array}$ & $-3,389$ & $* * *$ & $-3,511$ & $* * *$ & $-3,462$ & $* * *$ \\
\hline 37 & $\begin{array}{l}\text { Deniz Asset } \\
\text { Management } \\
\text { Equity Fund }\end{array}$ & $-3,432$ & $* * *$ & $-3,517$ & $* * *$ & $-3,483$ & $* * *$ \\
\hline 38 & $\begin{array}{l}\text { Finans Asset } \\
\text { Management } \\
\text { Second Equity } \\
\text { Fund }\end{array}$ & $-3,466$ & $* *$ & $-3,527$ & $* *$ & $-3,503$ & $* *$ \\
\hline 39 & $\begin{array}{l}\text { Garanti Asset } \\
\text { Management } \\
\text { Equity Fund } \\
\end{array}$ & $-3,567$ & $* *$ & $-3,460$ & $* * *$ & $-3,503$ & $* * *$ \\
\hline 40 & $\begin{array}{l}\text { TEB Asset } \\
\text { Management } \\
\text { Equity Fund }\end{array}$ & $-3,430$ & $* * *$ & $-3,572$ & $* *$ & $-3,515$ & $* *$ \\
\hline 41 & $\begin{array}{l}\text { Halk Asset } \\
\text { Management } \\
\text { Equity Fund }\end{array}$ & $-3,424$ & $* * *$ & $-3,609$ & $* *$ & $-3,535$ & $* *$ \\
\hline 42 & $\begin{array}{l}\text { Yapı Kredi Asset } \\
\text { Management BIST } \\
100 \text { Index Equity } \\
\text { Fund }\end{array}$ & $-3,516$ & $* *$ & $-3,620$ & $* *$ & $-3,578$ & $* *$ \\
\hline 43 & $\begin{array}{l}\text { Ak Asset } \\
\text { Management BIST } \\
30 \text { Index Equity } \\
\text { Fund }\end{array}$ & $-3,595$ & $* *$ & $-3,676$ & $* *$ & $-3,643$ & $* *$ \\
\hline 44 & $\begin{array}{l}\text { Ak Asset } \\
\text { Management BIST } \\
\text { Bank Index Equity } \\
\text { Fund }\end{array}$ & $-3,515$ & $* *$ & $-3,769$ & $* *$ & $-3,667$ & $* *$ \\
\hline 45 & $\begin{array}{l}\text { Yapı Kredi Asset } \\
\text { Management BIST } \\
30 \text { Index Equity } \\
\text { Fund }\end{array}$ & $-3,702$ & $* *$ & $-3,726$ & $* *$ & $-3,716$ & $* *$ \\
\hline 46 & İş Asset & $-3,699$ & $* *$ & $-3,790$ & $* *$ & $-3,754$ & $* *$ \\
\hline
\end{tabular}




\begin{tabular}{|c|c|c|c|c|c|c|c|}
\hline & $\begin{array}{l}\text { Management BIST } \\
30 \text { Index Equity } \\
\text { Fund }\end{array}$ & & & & & & \\
\hline 47 & $\begin{array}{l}\text { Vakıf Asset } \\
\text { Management BIST } \\
30 \text { Index Equity } \\
\text { Fund }\end{array}$ & $-3,762$ & $* *$ & $-3,774$ & $* *$ & $-3,770$ & $* *$ \\
\hline 48 & $\begin{array}{l}\text { Deniz Asset } \\
\text { Management BIST } \\
100 \text { Index Equity } \\
\text { Fund }\end{array}$ & $-3,826$ & $* *$ & $-3,759$ & $* *$ & $-3,786$ & $* *$ \\
\hline 49 & $\begin{array}{l}\text { Ziraat Asset } \\
\text { Management BIST } \\
30 \text { Index Equity } \\
\text { Fund }\end{array}$ & $-3,801$ & $* *$ & $-3,789$ & $* *$ & $-3,794$ & $* *$ \\
\hline 50 & $\begin{array}{l}\text { HSBC Asset } \\
\text { Management BIST } \\
30 \text { Index Equity } \\
\text { Fund }\end{array}$ & $-3,785$ & $* *$ & $-3,856$ & $* *$ & $-3,828$ & $* *$ \\
\hline 51 & $\begin{array}{l}\text { Finans Asset } \\
\text { Management Dow } \\
\text { Jones İstanbul } 20 \\
\text { (Equity Intensive) } \\
\text { Exchange Traded } \\
\text { Fund }\end{array}$ & $-3,833$ & $* *$ & $-3,829$ & $* *$ & $-3,830$ & $* *$ \\
\hline 52 & $\begin{array}{l}\text { İş Asset } \\
\text { Management BIST } \\
30 \text { (Equity } \\
\text { Intensive) } \\
\text { Exchange Traded } \\
\text { Fund }\end{array}$ & $-3,868$ & $*$ & $-3,889$ & $*$ & $-3,881$ & * \\
\hline 53 & $\begin{array}{l}\text { Garanti Asset } \\
\text { Management BIST } \\
30 \text { Index Equity } \\
\text { Fund }\end{array}$ & $-3,909$ & $*$ & $-3,909$ & $*$ & $-3,909$ & * \\
\hline 54 & $\begin{array}{l}\text { Finans Asset } \\
\text { Management BIST } \\
30 \text { (Equity } \\
\text { Intensive) } \\
\text { Exchange Traded } \\
\text { Fund }\end{array}$ & $-3,965$ & $*$ & $-3,950$ & $*$ & $-3,956$ & $*$ \\
\hline 55 & $\begin{array}{l}\text { HSBC Asset } \\
\text { Management } \\
\text { Equity Fund }\end{array}$ & $-4,153$ & $*$ & $-3,971$ & $*$ & $-4,044$ & * \\
\hline 56 & $\begin{array}{l}\text { İş Asset } \\
\text { Management BIST } \\
\text { Bank Index Equity } \\
\text { Fund }\end{array}$ & $-4,449$ & $*$ & $-4,332$ & $*$ & $-4,379$ & $*$ \\
\hline 57 & $\begin{array}{l}\text { Finans Asset } \\
\text { Management } \\
\text { Turkey Large-Cap } \\
\text { Banks (Equity } \\
\text { Intensive) } \\
\text { Exchange Traded } \\
\text { Fund }\end{array}$ & $-5,509$ & $*$ & $-5,289$ & $*$ & $-5,377$ & $*$ \\
\hline
\end{tabular}

www.spk.gov.tr (Capital Markets Board of Turkey) 
When the 57 equity umbrella funds are ranked according to the Morningstar rating system, the first 6 equity mutual funds that have the 5-star rating are, Ak Asset Management America Foreign Equity Fund, Ak Asset Management European Foreign Equity Fund, Yapı Kredi Asset Management Foreign Technnology Sector Equity Fund, Ak Asset Management Foreign Securities Fund, Gedik Asset Management G-20 Countries Foreign, Strateji Asset Management Second Equity Fund. The common feature of the first five funds is that they are foreign equity funds. The 6 equity umbrella funds that got the 1-star rating included iş Asset Management BIST 30 Index Equity Fund, Garanti Asset Management BIST 30 Index Equity Fund Finans Asset Management BIST 30 (Equity Intensive) Exchange Traded Fund, HSBC Asset Management Equity Fund, iş Asset Management BIST Bank Index Equity Fund, Finans Asset Management Turkey Large-Cap Banks (Equity Intensive) Exchange Traded Fund. The common feature of these funds is that they follow the index that invests in the indexed assets.

\section{CONCLUSION}

Mutual funds ensure that funds of investors with savings are managed by professional and reliable managers. To the investors, mutual funds also provide the following benefits.

- The array of securities that can be included into their portfolio like fixed income, foreign exchange indexed, and partnership interest instruments increase their diversification hence the possibility of reducing risks.

- With the valuation and control of securities, resources could be saved on collection and tracking of coupons, interest and dividends since they are carried out under the fund management.

- They provide opportunities for investment in high-potential securities which would otherwise be difficult for small savers.

- $\quad$ Since the value increases in the fund portfolio are reflected daily to the portfolio value, investors can convert their realized earning to cash to the desired amount or even as a whole.

- The portfolio saves time and money due to the large amount of transactions.

Even though mutual funds provide important benefits to investors, questions still persist on which funds investors will invest in. Determination of today's performance of mutual funds acts as an important source of information for comparisons with future performances. In this regard, the study used the Morningstar rating system to evaluate 57 equity umbrella funds operating in Turkey between the periods of January 2012 and December 2016. The results obtained in the study regarding performance rankings and performance are not meant as a prediction of the future performance of the concerned funds, they are only intended to assess the value of the equity umbrella funds at a specific period in the past using an internationally accepted rating system.

It was determined, according to the data obtained, that equity umbrella funds have an overall negative Morningstar performance result. The equity umbrella funds are considered to be underperforming since they performed poorly compared to the Treasury bills used in the study. As can be seen from the table above, only 3 funds have positive Morningstar score's even if 6 funds get the five stars due to Morningstar's rating metholodogy. Funds with the negative Morningstar scores and raw returns might get high star ratings in this rating sysyem. So that doesn't mean funds that have high stars always outperform and show superior performance. Also, it can be concluded funds that invest foreign securities perform better than the other funds. This might be the result of the lower volatility or in other words might arise from the more stable and sustained performance of the foreign stocks.

Under the assumption that past performance results will continue in the future, it is thought that the results are meaningful and should be followed. But on the other hand, Morningstar rating system should not be used as the sole indicator of the fund performances and should be used as the first step of the fund selection process. After that, it can be used to eliminate the alternatives and distinguish funds. Besides, other determinants related to fund performances need to be considered as well. Even if almost all the performance evaluation methods have several deficits, traditional measures like Sharpe, Treynor, Jensen ratios or the other methods that evaluates funds' performances can be used to get more comprehensive standpoints and to do more accurate analyzes and evalulations.

\section{REFERENCES}

Adkisson, J., A. and Fraser, D., R. (2003). Reading The Stars: Age Bias in Morningstar Ratings, Financial Analyts Journal, V.59, N.5, pp.24-27.

Aksoy, A. and Tanrı̈ven, C. (2007). Sermaye Piyasası Yatırım Araçları ve Analizi, 3. Baskı, Gazi Yayınevi, Ankara.

Antypas, A. Caporale, G., M., Kaurogenis, N. and Pittis, N. (2009) Selectivity, Market Timing and the Morningstar Rating-System, http://hdl.handle.net/10419/26625, pp.1-31, (20.10.2017).

Apak, S. and Taşçıyan K., H. (2009). Morningstar Yıldız Derecelendirme Sistemi ile Türk Emeklilik Yatırım Fonlarının Performanslarının Değerlendirilmesi, MUFAD, ss. 80-90.

Ayaydın, H. (2013). Türkiye 'deki Emeklilik Yatırım Fonlarının Performans Analizi, Ç.Ü. Sosyal Bilimler Enstitüsü Dergisi, C.22, S.2, ss. 59-80. 
Barron, J. and Ni J. (2013). Morningstar Rating and Mutual Fund Manager Turnover, Journal of Applied Finance, V.23 N.1, pp.95-110.

Black, C., R. and Morey, M., R. (2000). Morningstar Ratings and Mutual Fund Performance, The Journal of Financial and Quantitative Analysis, V.5, N.3, pp. 451-483.

Bolster, P., J. , Trahan, E., A., Wang, P. (2016). Assessing Performance of Morningstar's Star Rating System for Equity İnvestment, Journal of Economic \& Financial Studies, V.4, N.01, pp.11-22.

Blume, M., E. (1998). An Anatomy of Morningstar Ratings, Financial Analyts Journal, V.54, N.2, pp.19-27.

Choivetthamrong, C. (2015). The Performance of Thai Mutual Funds: A 5-Star Morningstar Mutual Fund Rating, Journal of Economics, Business and Management, V.3, N.1, pp.1-7.

Civan, M. (2010). Sermaye Piyasası Analizleri ve Portföy Yönetimi, I. Basım, Ekin Yayınevi, Bursa.

Gerrans, P. (2006). Morningstar Ratings and Future Performance, Accounting and Finance, V.46, N.4, pp.605-628.

Guercio, D., D. and Tkac, P., A. (2001). Star Power: The Effect of Morningstar Ratings on Mutual Fund Flows, Federal Reserve Atlanta Workingpaper Series, 2001-15, pp. 1-49.

Jensen, M., C. (1968). The Performance of Mutual Funds in the Period 1945-1964, The Journal of Finance, V.23, N.2, pp. 349-416.

Kaur, J. ve Liu, L. (2010). Predictability of Morningstar rating for future performance on Canadian mutual funds. Simon Fraser University FRM Research Project, pp.1-29.

Knuutila, M., Puttonen, V. and Smythe, T. (2007). The Effect of Distribution Channels on Mutual Fund Flows, Journal of Financial Services Marketing, V.12, N.1, pp.88-96.

Loviscek, A., L. and Jordan, J. (2000). Stock Selection Based or Morningstar's Ten-Year, Five-Star General Equity Mutual Funds, Financial Services Review, V.9, pp.145-157.

Morey, M., R and Vinod, H., D. (2001). Estimation Risk in Mutual Fund Ratins: The Case of Morningstar, https://papers.ssrn.com/so13/papers.cfm?abstract_id=2702348rec=18srcabs=4552408alg=18pos=3, pp.1-18, (01.10.2017).

Morey, M., R. (2002). Mutual Fund Age and Morningstar Ratings, Financial Analysts Journal, V.58, N.2, pp.56-63.

Morey, M., R. (2003). The Kiss of Death: A 5-star Morningstar Mutual Fund Rating, SSRN Electronic Journal, https://ssrn.com/abstract=455240, $(01.10 .2017)$

Morey, M., R. and Gottesman, A., A. (2006). Morningstar Mutual Fund Rating Redux, SSRN Electronic Journal, https://www.ssrn.com/abstract=890128, (01.10.2017).

Sharpe, W., F. (1966). Mutual Fund Performance, Journal of Business, V.39, N.1, pp.119-138.

Sindell, K. (2005). Investing Online for Dummies, $5^{\text {th }}$ Edition, Wiley Publishing, New Jersey.

Treynor, J., L. (1965). How to Rate Management of Investment Funds, Harvard Business Review, V.43, N.1, pp. 63-75.

www.spk.gov.tr/Sayfa/AltSayfa/253, Date of access: 12.12 .2017

https://www. spk.gov.tr, Date of access:10.12.2017 